The development of this project has taken place in three phases. The first, in 1948-9, was a thorough investigation of the area and its potentialities by the Department of Agriculture. The second phase comprised preliminary work, such as the construction of roads and essential buildings, including accommodation for staff and workers, the laying on of water supplies, and the stocking up in advance of vital stores. The third phase, which is now in progress, comprises agricultural development and the settlement of tenant farmers. In this final phase an important contribution is being made by the Department of Agriculture, which is running an experimental station, and by the Forestry Department, which has established a nursery and advises on the tree-planting programme.

The land on the Damongo Scheme will be divided into units of 4,000 acres, each in charge of one of the Company's officers, who will be responsible for the settlers on the unit. Including families and dependants, there will be about 750 people on each unit, which will be self-supporting and self-financing.

Each tenant farmer has a holding of 28 acres and is provided with a well-built house, comprising two rooms and a veranda, to which he is encouraged to add if he wishes. Of the 28 acres, 18 will normally be under crops while the remainder is being rested. The principal crops grown are guinea corn, maize, and groundnuts. The Company clears, ploughs, fertilizes, and plants the land, which is divided into plots of about two acres, according to the contour of the ground, to prevent soil erosion. The tenant farmer's share of the work is the weeding of the land and harvesting. The crops harvested are divided in the proportion of two-thirds to the Company and one-third to the tenant farmer, except in the case of yams where the proportions are reversed as all the cultivation of yams is undertaken by the farmer.

Each tenant farmer also has a two-acre plot for his personal use, on which he grows vegetables such as tomatoes, beans, sweet potatoes, and peppers. He can keep these for his own use or augment his income by their sale.

Medical facilities already available include a dispensary, out-patients' rooms, doctor's surgery, and laboratory. A 40 -bed hospital is under construction and an operating theatre is to be built. The hospital will cater for the whole of the Western Gonja District and will cost $£ 40,000$, which will include the provision of full equipment, drugs, lighting, and a water-borne sewerage system. Quarters for the junior medical staff-eight three-roomed houses-are sited near the hospital. A doctor is already at work and the training of African nurses is due to start shortly.

Housing for employees already completed comprises i 50 single-room labourers' quarters; a further 250 will be built. A good water supply is obtained from a borehole, sunk by the Department of Rural Water Development, which yields 800 gallons an hour, and two further boreholes are due to come into use within the next six months.

\title{
United Nations Trusteeship Council: Visiting Mission to Tanganyika
}

THE Governor of Tanganyika, Sir Edward Twining, addressing the Trusteeship Council of the United Nations at New York on 20 June r 952 commenting on the report of a Visiting Mission which was in the territory in August and September $195 \mathrm{I}$, said that he was much impressed by the objectiveness of the critical approach of the Visiting Mission's report, but the need for greater speed in development, which was urged by the Mission, did not mean that the Tanganyika Government had no sense of urgency. It often seemed that the Government's plans to make the territory the place they felt it ought to be did not move fast enough, but there were many factors which conditioned the rate of progress, such as the time taken to train local staff, the difficulty of recruiting and housing staff from overseas, delays in the delivery of supplies and the limitations of finance. Tanganyika, he said, was a country of 
great distances with a relatively small and scattered population, and much of the country had poor soil, or lacked water, or was infested with tsetse flies. The African people, too, were unaccustomed to a hurried life and had a genius for enjoying their leisure.

'Of all the problems with which I am faced in 'Tanganyika', he said, 'this one of increasing the speed of progress is the most intractable. Moreover there is a fear among many Africans that our passion for speed may destroy many things they cherish before they have been replaced by something better. ... We intend to build a lasting structure, and we must move surely, even if slowly. I believe that, as we proceed, our tempo will gather momentum, and this view is borne out by the remarkable progress that has been made.'

\section{Margaret Wrong Prize}

THIs Prize will be offered annually by the Trustees of the Margaret Wrong Memorial Fund for original work by writers of African race living in a part of Africa to be decided upon each year by the Trustees.

\section{Results of Competition-i95 I}

This Competition was open to competitors from Gambia, Sierra Leone, Nigeria, Gold Coast, Liberia, French West Africa, French Equatorial Africa, and the French Cameroons.

The Silver Medal and Prize of $f, 5$ has been awarded to

A. Davidson Nicol of Sierra Leone, for a story 'The Devil of Yelahun Bridge'.

\section{REGULATIONS FOR I953}

I. A silver medal and a money prize not exceeding $f 5$ will be offered in 1953 .

2. In I 953 manuscripts are invited from the Union of South Africa, the High Commission Territories, and Madagascar.

3. The length of manuscripts should be not less than 5,000 or more than I 5,000 words.

4. The language may be English, Afrikaans, or French.

5. The manuscript must be of an imaginative character or descriptive of African life or thought, and suitable for general reading.

6. Each manuscript should be accompanied by a statement signed by the author declaring that it is his own unaided work and has not previously been published.

7. Manuscripts should be addressed:

$$
\begin{aligned}
& \text { THE MARGARET wrong PRIzE, } \\
& \text { c/o The International Committee on } \\
& \text { Christian Literature for Africa, } \\
& \text { 2, Eaton Gate, } \\
& \text { London, S.W. I. }
\end{aligned}
$$

8. Manuscripts must reach the London office of the International Committee on Christian Literature for Africa before $3 \times$ December 1953.

9. In the award of the Prize the decision of the Trustees will be final. 